\title{
Sharing Autobiographical Memories in English COMPUTER-Mediated Discourse: A Linguist's Perspective
}

\begin{abstract}
In linguistics, autobiographical memory is currently under research as a basis for a number of literary genres, namely, memoirs, autobiographies, and diaries. As such, it has been narrativized to a great extent. The narrative in its classical understanding that goes back to Labov's definition has been traditionally viewed as a standard form of representing autobiographical recall reports. In this paper, the author argues that the role of the narrative in its original narrow meaning presupposing the chronological succession of events has been significantly exaggerated when it comes to verbal manifestation of memory. As the society is getting accustomed to innovative ways of communicating information, there develop new forms of representing existing language phenomena. This article presents the author's findings as regards forms of sharing autobiographical memories in English computer-mediated discourse. Upon analyzing a significant number of collected samples, the author arrives at the conclusion that the retrospective monologue is a recurrent verbalizer of autobiographical memories in English online communication and aims at identifying and describing its structural, communicative, and discourse features in this quality.
\end{abstract}

Keywords

Memory; autobiographical memories; computer-mediated discourse; retrospective monologue

\section{Introduction}

Memory, both as a property of human mind and a socio-cultural phenomenon, has long been in the focus of scientific research. The past decade has seen an upsurge 
in interest shown by researchers towards autobiographical memory, a special subsystem of an individual's declarative memory storing information about past events personally experienced by the individual. In linguistics autobiographical memory has been examined from different angles: as a component of life-writing (Olney 1998; Anderson 2001; Smith and Watson 2010; Kucała 2017), in connection with its content and linguistic characteristics of memory narratives (Tani et al. 2015), as regards gender differences in memory reports (Smith 1987; Smith and Watson 1998; Anderson 1996), in the light of complex relationships between memory and identity (King 2000), etc. One cannot fail to notice the obvious tendency dominating all linguistic studies of the subject: whichever aspect of autobiographical memory is under analysis, it is presumed by default that its verbal representation always takes the form of a narrative.

The tendency to narrativize memory is so strong that some scholars actually equate autobiographical memory with narrative. For example, Nelson (2003a: 20) claims that "an autobiographical memory itself can be considered as one very long narrative, the story of one's life with many ministories incorporated into it" and suggests considering narrative "as a thread that binds our memories, our selves, our social partners, and our culture together". Narrative, according to Finlayson and Corman (2013: 174), is "tailor-made to communicate complex constellations of actors, motivations, plans, goals, actions, causes, and effects in a succinct, easily-digestible format". Thus, narrative as a verbalizer of autobiographical memory is not just a description of a list of events displaying only basic coherence. Narratives, to quote Nelson (2003b: 126), "situate action in time and place, introduce agents, connect events through mental and physical causal and temporal sequences moving towards a goal or outcome". Discussing the structure of the remembered events, Nelson (2003a: 13) describes the process of memory narrativization in the following way: "The narrative form takes a mundane event, gives it a setting of time and place, provides a central action or goal, a motivation, highlights a highpoint of surprise, success, or failure, an emotion, a conclusion, and an evaluation". Not denying the significance of narrative for the construction of memory reports, I still consider it reasonable to turn to other language forms potentially capable of verbalizing mnemonic content but consistently ignored by researchers.

The recent shift towards computer-mediated communication along with the appearance of new online forms and genres made me doubt the status of the narrative as an exclusive form of representing autobiographical memory. Previous findings suggest that the narrative is not the only language structure capable of representing mnemonic content in an organized form (Tivyaeva 2014). Personal past experience can also be verbalized via a number of language structures, the retrospective monologue being one of the many. The focus of this paper is on the retrospective monologue as a means of representing autobiographical memory.

The article has three aims. Firstly, I begin by reviewing research on the retrospective monologue in order to clarify the term and investigate the potential of the retrospective monologue in representing autobiographical content against 
that of the narrative. Secondly, I describe recent structural, communicative and discourse changes of the retrospective monologue caused by its new role as a verbalizer of autobiographical memory in English computer-mediated discourse (CMD). Finally, I examine how widespread the retrospective monologue is in different varieties of English CMD.

\section{Data and Methods}

To investigate the potential of the retrospective monologue as regards verbalization of autobiographical memory, relevant empirical data was manually collected, specifically, textual fragments presenting past personal experience told in first-person mode totalling over 1,000 items.

To differentiate retrospective monologues from memory narratives, I relied primarily on the definition of narrative generally accepted and widely used by narratologists and scholars of autobiographical memory. For example, Fivush (2011: 561), a renowned expert on memory and life narrative, defines narratives as "canonical linguistic forms that specify a sequence of actions and provide an explanatory and evaluative framework for understanding the event". Briefly, the definition of narrative as quoted as well as employed by researchers (for example, (Chafe 1990; Linde 1993)) in other wordings states that a narrative is 1) a temporarily organized sequence of events 2) that are causally linked and 3) presented by the narrator in a manner conveying his or her subjective view and evaluation of the events.

Thus, contrasted to narrative that follows events and characters in their development, the retrospective monologue is not focused on chronology and sequences, but rather describes a single major/minor event or a chain of events, not necessarily placed into an evaluative context. Moreover, unlike narrative, which is characterized by a specific internal structure consisting of six (Labov 1972: 370) or seven (Rothery and Stenglin 1997: 244) elements, some being optional, others obligatory, the retrospective monologue does not have any rigid structural model underlying it and does not proceed through any stable stages.

If considered in terms of the concept of story genres proposed and developed by representatives of Sydney school (Plum 1988; Eggins and Slade 2005; Martin and Rose 2008) to distinguish between different types of storytelling texts, the retrospective monologue may represent anecdotes, exemplums, recounts or observations which are, just like narrative, specific subcategories of "story". Narrative as a storytelling genre is differentiated from the other narrative-like genres due to its generic structure consisting of a complication and resolution while the other genres are based on different experiences. Thus, the core of the anecdote is construed by a remarkable event and a reaction to it; the exemplum is focused on an incidence and its interpretation; the recount is just a record of events complying with expectations while the observation presents a description of an event along with a comment to it (Martin and Rose 2008). The four variants of story 
lack a complication in their generic structure, so that is another important property characteristic of the retrospective monologue.

For a further differentiation between memory narratives and retrospective monologues, the criterion of the communicative situation proposed by Cohn (1983) was used. In her analysis of literary narratives Cohn (1983) classifies first-person narratives according to two criteria, namely, distinctions between problematic and unproblematic communicative situations and distinctions between the chronological and achronological order of narrated events. On the basis of the former monologues as dealing with problematic situations are contrasted to narratives as conveying unproblematic situations. As for the latter, in this paper I argue that the requirement of the chronological order suggested by Cohn (1983) cannot be applied to autobiographical monologues as numerous examples demonstrate that autobiographical content can be presented achronologically and still remain what it is, namely, life-writing or life-telling. This and other intricacies of terminology will be dealt with later on in the section on the retrospective monologue as a literary and linguistic phenomenon.

The paper is based on a data set containing 1,063 items which were extracted from three sub-corpora representing three varieties of CMD: mass media discourse, social media discourse and diary discourse respectively. Sub-corpus 1 includes mass media discourse samples collected from websites of British and American newspapers and magazines (specifically, The Guardian, The Daily Mail, The Daily Telegraph, Newsweek, The Daily Beast, and MarieClaire). Subcorpus 2 contains social media texts retrieved from Facebook, discussion groups and forums hosted on The Guardian website (the Witness and Notes \& Queries sections), and anonymous confessions websites (www.simplyconfess.com, www. secret-confessions.com). Sub-corpus 3 consists of fragments from personal online diaries retrieved from relevant websites (www.diary.com and www.my-diary. org). Texts in all of the three corpora are thematically coherent and deal with the same topic: autobiographic memories. For the purpose of obtaining unbiased results, the collected sub-corpora are of the same volume and each one incorporates text fragments totalling approximately an equivalent of 500 pages.

The corpora were evenly searched for retrospective monologues. An item was registered as a retrospective monologue if it met the following conditions: 1) first-person narration mode, 2) autobiographical content independent of broader past experience context and falling outside the evaluative framework, 3) problematic communicative situation (dealing with a problematic episode from the past rather than presenting a general memory about the course of life).

As dictated by the goals of this paper, a combination of research methods and practices was used. Theoretical methods consist in critical review of prior inquiries into the nature, types and functions of the retrospective monologue and comparison of existing approaches to defining the retrospective monologue and identifying its varieties. Empirical methods include the continuous sampling method used to collect language data; the linguistic observation method, text analysis and interpretation, contextual and discourse analysis used to identify retrospec- 
tive monologues and describe their features relevant to the aims of this study; the statistical method applied to empirical material to obtain data on distribution of various types of retrospective monologues across varieties of CMD and occurrence of retrospective monologues displaying certain distinctive features.

\section{Overview}

\subsection{Retrospective monologue vs. memory monologue}

The retrospective monologue was traditionally viewed by linguists as a means of organizing the internal structure of a literary text and a device allowing the reader to look into the inner world of the text's protagonist by getting a first-person account of his or her thoughts and feelings. Thus, it was studied mostly by literary critics and researchers working in the field of text linguistics and narratology. As indicated above, the focus of this paper is the retrospective monologue as a means of verbalizing autobiographical memory, which makes my investigation pursue a direction new for the subject matter of this inquiry. However, before proceeding any further with identifying and describing its features and peculiarities as such, it seems necessary to clarify the meaning of the term 'retrospective monologue' as this linguistic phenomenon has been known to researchers under different names, each bearing some additional shades of meaning.

'Retrospective monologue', or 'retrospective soliloquy', is the term used both in the Russian (Guseva 2003; Kirillova 2011; Sergeeva 2009) and Western (Chiu 2014; Gottskálk 2004; Harty 2009; Phillpotts 2011; Russo 2002; Schroeder 1989) narratological and linguistic traditions. Alternatively, the same language phenomenon is often referred to as 'memory monologue' by scholars (Fludernik 2004; Nikolajeva 2002; Richardson 2006; Sharma 2004) following the typology proposed by Cohn (1983: 247) who defines the memory monologue as a variant of an autonomous monologue (that is, a monologue devoid of any signs indicating the narrator's presence) "in which the mind is trained full-time on the past". Memory monologues are past-oriented and disorderly, they break the spatial-temporal continuum of the text, breaching the progressive development of narrated events and making the reader follow the remembering mind of the reminiscing character back into the past. Thematically they are free-associational, that is, not related to any specific personal experience of the past. Cohn (1983: 247) states that "in memory monologues the present moment of locution is a moment emptied of all contemporary, simultaneous experience: the monologist exists merely as a disembodied medium, a pure memory without clear location in time and space". Analyzing various narrative techniques, she lists the following criteria of a memory monologue: the indeterminate monologic situation, the focus on the past and the a-chronological structure, stressing special importance of the latter.

The memory monologue in Cohn's typology is opposed to the autobiographical monologue which, like its counterpart, is produced in a problematic 
communicative situation but reveals past events experienced by the protagonist in the temporal order. However, this distinction does not have a sound foundation supported by empirical evidence. Language data collected in the course of my inquiry into the subject suggests that autobiographical content can be presented a-chronically in a monologically organized utterance.

This observation is illustrated by example (1) below, which is a fragment of a larger autobiographical monologue posted on The Guardian's website. The monologist is a student of midwifery who recalls her first experience of delivering a baby. She starts her story with a description of the actual event, the temporal marker 'last night' placing it on the time scale. After a short introduction, however, the storyline shifts to an earlier period as the author shares her expectations prior to the process (the shift is signaled morphologically, the past perfect form 'had imagined' indicating precession). Stating that the real experience was quite different, the monologist goes on to describe events of the previous night, occasionally breaking the originally set temporal continuum to make comments on her present, those jumps back and forth along the timeline marked by temporal adverbials. Thus, the monologue deals with an autobiographical event presented in the anachronic order.

(1) Last night I delivered a baby. [...]

I had imagined, like all student midwives, what my first delivery would be like. Nervous but excited expectant mum, supportive partner $[\ldots]$.

It seems obvious to me, however, that I was destined to embark on this career. There is no question of me backing out now. [...]

Yet, walking home after my 14.5-hour shift (I was desperate to stay beyond my allocated 12.5 hours, convinced the moment I left the room the mother would deliver) I felt a bit lost. It was $10.30 \mathrm{am}$. I had started my shift at 8.30pm the night before. (Greenwood 2015, Courtesy of Guardian News \& Media Ltd) ${ }^{1}$

This discrepancy between language facts and Cohn's typology of retrospective accounts of events was noted by other researchers as well. For example, analyzing Peter Weiss's prose from the position of literary studies, cognitive linguistics and cognitive science combined, Abrantes (2010: 155) points out that Cohn's interpretation of the autobiographical narrative as combining chronology with the aproblematic communicative situation is true "for the most part of the texts", although there are cases when "the chronological order is sporadically abandoned for specific narrative purposes". A similar observation regarding memory monologues was made by Ioannidou (2013) in her PhD thesis on Greek autobiographical fiction. Discussing Axioti's works, Ioannidou (2013: 96) remarks that she "uses autobiographical material without adhering to a well-defined time line" and then continues to suggest that "incidents from different stages of the author's life are combined together in an unsystematic manner and create the impression that 
a clearly outlined chronology of events followed in other forms of autobiographical writing is not an issue here".

It seems more logical to consider the autobiographical monologue a thematic variety of the memory monologue relating to past events of the speaker's personal life while the memory monologue in general dwells upon past happenings of any sort reconstructed from the protagonist's memory. So the distinction between the memory monologue and the autobiographical monologue as its subtype is related to the nature of narrated events, not to the temporal order in which they are conveyed. The memory monologue can represent recollections of historic events, for example, such as resignations and assassinations of political leaders or terrorist attacks (the so called 'flashbulb memories'), while the autobiographical monologue is thematically limited to verbalized everyday memories.

Hence, the use of terms 'autobiographical monologue' and 'memory monologue' for notions standing in hyponymic relations seems confusing and misleading, therefore, taking all the foregoing into account, I consider it expedient to stick to the term of 'retrospective monologue' for referring to a past-oriented monological utterance and use the term 'autobiographical monologue' to describe a variety of the retrospective monologue presenting a recountal of personal memories regardless of the temporal order. It is these particular meanings that will be assigned to the relevant terms in this paper from this point onward.

\subsection{Retrospective monologue vs. interior monologue}

Another point that needs to be clarified regarding the retrospective monologue is its status in relation to the interior monologue. Results of earlier investigations (Cohn 1983; Humphrey 1954; Kirillova 2011; Sergeeva 2009) concerned mostly the non-verbalized variety of the retrospective monologue, that is, the interior monologue as a component of the protagonist's inner speech, since this is the kind we most often come across in fiction. In Cohn's (1983) conception of firstperson narration the autobiographical and memory monologues are contrasted to the "genuine interior monologue". Researchers adhering to a different point of view consider the retrospective monologue a subtype of the interior monologue. For example, Kirillova (2011: 109) classifies the former as an interior monologue expressing a statement and describes it in the following way:

Retrospective monologues contain descriptions of past events presenting memories, faces, and the world that will not return. Consciousness snatches selected life episodes from memory, thus revealing the character's past along with his mindset. As a rule, the basis for retrospective monologues is associative linking of images of the past with those of the present. (my translation)

Obviously, the concept of the retrospective monologue being a variety of the internal monologue, the latter provisionally defined by Tumanov (1997: 142) as 
"the inner speech of the fictional character" is no longer true to reality and can be easily invalidated by empirical evidence. I say "no longer" because when the retrospective monologue originated ${ }^{2}$ and gained extensive popularity ${ }^{3}$, it actually was a literary technique aimed at revealing the protagonist's inner world and characterizing him or her by means of speech representation. In this paper I will argue that the retrospective monologue is not a subtype of the interior monologue, but an independent type of the autonomous monologue that has outstepped fiction texts (just like it had once extravagated beyond the bounds of drama) to find itself widely used in other genres and discourses. Moreover, being a larger category than the retrospective one, the solo monologue actually became an independent genre in the United States and, as noted by Paterson (2015), flourished during the latter years of last century.

As suggested by language data, two types of the retrospective monologue can be differentiated in accordance with the channel of speech representation: the external retrospective monologue and the interior retrospective monologue. The difference between the two is the same as between the external and the interior monologue proper, that is, the external monologue is actually verbalized by the fictional character whether orally or in writing, while the interior monologue is never or only partially uttered, its contents being presented to the reader as a direct quotation from the protagonist's inner discourse. Describing the interior monologue, Bal (2004) likens the rendering of the character's mind in this format to tape-recording their thoughts. The two types of the retrospective monologue are illustrated by examples 2 and 3 .

(2) "Here's a way that might help you understand what's going to happen to you. Growing up, in Brooklyn this was - near where you met up with the guy with the ponytail, actually - I went to Catholic grade school. I'll never forget this one. Parish priest gives an inspirational talk to our class. Sixth grade, I think it was. The talk is all about eternity, eternal damnation, and how to comprehend it, as if that's possible. The priest says, 'Imagine there's this tiny little blackbird, lives on a huge mountain in upstate New York or some other godforsaken place. And every thousand years, that little bird fills its beak with whatever it can carry and flies down to Brooklyn and deposits its mouthful in our school parking lot. Now, imagine that the blackbird does this until the entire mountain has been transported there. And that, ladies and gentlemen, would be just the beginning of eternity.'

"Here's another thought for you. This whole nightmare, all of it, it's been going on for about thirteen seconds. Start to finish, thirteen seconds. Count 'em - thirteen. So do you see how horrible an eternity of this would be?" (Patterson and Roughan 2008) 
(3) Shame makes a haze of memory. Sharon still could not recall the precise chronology of what happened that evening at the Voigt home. Well, he came to the rear door. Rapped on the glass with his knuckles. Grinned at her. "Hey, toots: want some company?" Did Sharon open the door? Or had Ryan Voigt opened it? It was just past 9:30 p.m. The Voigts had driven to Buffalo to visit relatives and were due back, Mrs. Voigt had promised, around 11 p.m. Sharon had babysat for Mrs. Voigt twice before, she knew the house and felt comfortable in it. She would have locked the door from the inside (as Mrs. Voigt had instructed) but Ryan Voigt had his own key, didn't he? He was part owner, wasn't he? It was the sequence of small moments, remarks, actions that would elude her. She felt, now, that recollecting the events was like trying to piece together a sheet of broken glass. (Oates 2009: 111)

Fragments (2) and (3) are both retrospective monologues supplying the reader with information about events in the past. However, the manner in which the narrated events are presented is not the same. While the primary focus of the external retrospective monologue (2) is on conveying sheer facts, fragment (3) centres around the monologist's psyche offering the reader an insight into her consciousness. Concentration on processes of the reflective mind along with the contents is typical of the interior monologue in general, the main function of which in the literary text, as formulated by Humphrey (1954: 24), is "representing the psychic content and processes of character ... just as these processes exist at various levels of conscious control before they are formulated for deliberate speech". The same is true for the interior retrospective monologue. Guseva (2003) points out that this kind of monologue is focused on the reflective character's consciousness tracing events in retrospection while Sergeeva (2009) concludes that one of the functions performed by the retrospective interior monologue in the text consists in conveying autobiographical data and thus characterizing the character psychologically.

As it is demonstrated by examples (2) and (3) and further supported by more empirical evidence, memory reports can be transferred by different channels. The verbal channel produces exteriorized recalls while unuttered mnemonic experience is represented as the interior retrospective monologue. Extensive use of the retrospective monologue in stream of consciousness literature of the $20^{\text {th }}$ century made many literary critics equate it with the interior monologue, however, this point of view contradicts linguistic facts, therefore, the retrospective monologue should be recognized as an independent past-oriented monologue type, not a variety of the interior monologue. Since it can also be interiorized, it does have some features in common with the latter (for example, both can be direct and indirect), but as an autonomous type with an open form allowing for modifications, it has developed a number of new ones, specifically, structural, semantic and communicative, that will be dealt with in the following section. 


\section{Results and discussion}

As it was mentioned in the previous section, earlier investigations by literary critics concerned mostly the non-verbalized variety of the retrospective monologue, for this is the kind we most often come across in fiction. However, the past two decades witnessed a change in the shape and form of the retrospective monologue as a new type of discourse emerged along with new communication technologies. This section of the paper is devoted to newly evolved varieties of the retrospective monologue found in English CMD and their structural and functional peculiarities both shared with its print counterpart, which is commonly used in fiction, and unique to the online type.

\subsection{Distribution of retrospective monologues across varieties of CMD}

Accepting the definition of CMC as "the process by which people create, exchange, and perceive information using networked telecommunications systems that facilitate encoding, transmitting, and decoding messages" (December 1996), in this paper I will focus mainly on the textual aspect of CMC, for, unlike oral forms of communication, written texts can be saved and examined for research purposes. As noted by Herring (2001), CMD is no longer seen as a single mode. Text-based CMC presupposes exchanging online messages in different modes, such as blogs, chats, discussions, bulletins, conferences, comments, and others. These form varieties, however, can be organized into three groups in accordance with the subtype of CMD in which they typically occur. In the course of this investigation retrospective monologues were registered in the following three $\mathrm{CMD}$ subtypes: mass media discourse, social media discourse, and diaristic discourse. Empirical data shows that retrospective monologues presenting autobiographical content are quite frequent in all of the three, however, at present, mass media discourse seems to be the dominant area of occurrence. The results as regards the occurrence rate of the retrospective monologue in different types of discourse are presented in Table 1.

Table 1. Occurrence rate of retrospective monologues in different varieties of English computer-mediated discourse

\begin{tabular}{lc}
\hline Discourse variety & Occurrence rate \\
\hline Mass media discourse & $53 \%$ \\
Social media discourse & $17 \%$ \\
\hline Diaristic discourse & $30 \%$ \\
\hline
\end{tabular}

The high occurrence rate for mass media discourse is a consequence of a wider choice of genres and forms available to authors producing mass media content in English. Retrospective monologues have been registered in the following digital mass media genres thus far: articles, interviews, editor's columns, obituaries, 
blogs, commentaries, etc. The genre repertoire of social media discourse providing functioning space to the retrospective monologue is limited to social media posts and comments, while diaristic discourse is presented only by online diaries. Hence, the figures obtained in this inquiry are consistent with the functional potential of each discourse variety.

\subsection{Properties common to online and print retrospective monologues}

The results yielded by the qualitative analysis of the collected data permit to draw the conclusion that English online retrospective monologues incorporate a number of unique features alongside with features they have in common with their counterparts found in works of fiction. In this subsection I will deal with structural, communicative and thematic properties of the online retrospective monologue that can also be observed in print retrospective monologues. Just like the latter, online variants of the retrospective monologue serve to the same purpose - that of verbalizing autobiographical memory. In this quality they are used by online journalists, bloggers, diarists, and social media users as digitalized past-oriented first-person reports about personal events. Although it is more than logical to assume that all of them are direct exterior retrospective monologues since English CMD is characterized by focus on first-hand experiences communicated to the audience directly, not mediated by a narrator as it is often the case in fiction, the collected database of empirical material includes a few items (under $1 \%$ of the total number of entries) that can be classified as indirect and hybrid types. While all of the illustrative examples in this paper are direct retrospective monologues, fragments (4) and (5) represent indirect and hybrid types respectively.

(4) One night, when her client was in the bathroom and the guard had left her door, she saw her chance. She bolted from the bedroom and made it as far as the entrance to the building, where she was caught. The pimp marched her to the torture room, where he strung her up, arms spread, "like Jesus," she says, and whipped her with a rattan cane until she bled, then rubbed hot chilies into her wounds. After that, the pimp sold her to another brothel. (Pesta 2011).

(5) In a house just north of the city of Aleppo where the family has taken refuge, Saima grimaces as she recalls Feb. 11, the day that regular Syrian Army soldiers had come to their pro-rebel neighborhood in Homs. The soldiers searched the houses, smashing furniture and beating the men with rifle butts. That was merely a prelude for the raid an hour later when the Shabiha arrived.

Drawn mostly from Syria's minority Alawite sect, the thuggish militia has been blamed for many of the worst excesses in the conflict. "I recognized some of them. They were from Alawi districts nearby. They were our neighbors, too," she says, shaking her head in disbelief. "I was sitting 
with my 'sister-wife' and a friend and our children. The Shabiha ordered us to stand, screamed at us and started to fire wildly." (Dettmer 2012).

Example (4) illustrates the case when communication between the reader and the reminiscing monologist is conducted with the aid of the narrator incorporating memories of the latter into his story. The indirect way of representing autobiographical facts from the life of the girl interviewed for the article entitled "Diary of an Escaped Sex Slave" allows that the author place special emphasis on the factual information, not on the emotional drama she is going through.

Hybrid retrospective monologues (as in fragment (5)) combine elements of direct retrospective monologues with those of indirect retrospective monologues. Structurally, they are retrospective blocs of text including direct monological first-person utterances with embedded fragments of the narrator's speech. This format is especially effective in mass media discourse as, on the one hand, direct speech of the recollecting person contributes to the veracity of the story while giving the author the freedom to quote selected fragments, unobtrusively serving his or her intention, on the other hand.

The area of occurrence of indirect and hybrid retrospective monologues within English CMD is limited to mass media discourse as these two varieties were not registered in social media texts and online diaries. This fact is explained by the specifics of mass media texts which are similar to fiction in the way their content is presented to the reader. While in diaries and in social media texts the central figure of the story and the story-teller is the same person, in mass media discourse they often are distinct, so the choice of the format for representing autobiographical memories is determined by the author's pragmatic intention.

Other features shared by retrospective monologues in fiction and in CMD concern their communicative orientation and thematic organization. Communicatively, two types of retrospective monologues have become apparent: speaker-oriented and listener-oriented. The first type correlates with the introvert behaviour, the other one is more typical of extrovert monologists. While both types were detected among the collected data, it should be noted that the listener-oriented type outnumbers the speaker-oriented one in CMD (89\% against $11 \%$ respectively in accordance with the collected data), which is in tune with the general idea of online communication, that is, creating content to be publicly shared in the shortest time possible. This outward orientation is often manifested by minor details, such as vocatives or questions (as it is the case in example (6) below which is a fragment of a larger retrospective monologue) typically used in dialogues.

(6) Helping a young woman with postnatal depression was terrifying, but it was all part of my job as a junior doctor.

Do you like the smell of a new baby? That mix of fresh cotton, talc and baby wipes? I remember that smell now and rather than feel a lovely warm sense of "Aaaaah, isn't she cute", I'm reminded of abject horror. 
The last time I held a baby was several months ago at my perinatal psychiatry clinic. I was running the junior doctor slot for "non-complex cases". [...] (Anonymous 2016, Courtesy of Guardian News \& Media Ltd)

As for the thematic organization of retrospective monologues, two types have been identified in accordance with the way autobiographical information is presented. Retrospective monologues describing single episodes from the life of the recollecting person belong to the one-event type. The multi-event type includes an account of a string of autobiographical events following one after another. As a rule, one-event (episodic) retrospective monologues deal with some prominent, non-trivial events in the life of the monologist that either left a long-lasting trace in their memory or for some reason hold significance at the moment of speaking.

For example, in passage (6) above the author recalls an episode from her clinical practice which she qualifies as "terrifying". The case of severe postnatal depression she had to work with as a junior psychiatrist got firmly impressed in her memory because the baby's life was in danger. Example (7) below illustrates a multi-event retrospective monologue. The monologist lists facts from her past life focusing on consequences of her decisions that led to her current status.

While one-event retrospective monologues usually centre on the speaker's emotions, in multi-event ones a special emphasis is put on the succession of events and their results, therefore, it is typical of them to include much precise information, such as names, dates, places, etc. In example (7) the monologist mentions the city of Baghdad (location marker) and how long her marriage lasted (temporal marker).

(7) "Before the war, I was married, settled with my husband of nine years," she says. "He disappeared. I don't know where he is now." She echoes a sentiment shared by many of her peers: "There were prostitutes in Baghdad, but I thought they were just bad girls. I never thought I would be one of them." (Pergament 2008)

The two varieties are found both in fiction and in CMD. As for the latter, the data obtained in the course of this study shows that one-event retrospective monologues are a more common type with the occurrence rate of $82 \%$.

Thus, as suggested by results, the way of speech representation, communicative orientation, and thematic organization are characteristics typical of both fictional and online retrospective monologues.

\subsection{Properties uncommon for online and print retrospective monologues}

Linguistic features unique to the online type of the retrospective monologue are manifested at different levels and caused by specifics of CMD. The most striking difference between the two types is the interactive potential of the retrospective monologue in CMD. All other properties of online retrospective monologues are 
derivatives from its interactivity, which in the context of this inquiry I understand as openness to contact and interaction with readers, which is in accord with the general tendency of the Internet for publicity and accessibility over intimacy and privacy of print literature. This quality of online retrospective monologues determines their specific structure, content, and language.

Structurally, two types of digital retrospective monologues are apparent: homogeneous and non-homogeneous. This distinction is related to the way of presenting autobiographical information. When autobiographical facts are presented via the verbal channel, as an utterance, such a memory report is a homogeneous one. However, when personal life facts are supported by iconistic information, the resulting outcome is a non-homogeneous retrospective monologue combining visual and verbal elements, each of them contributing to revealing the monologist's life story. In the database the total number of non-homogeneous monologues amounted to $47 \%$ prevailing in specific genres, such as blogs and diaries.

The phenomenon of deverbalization, that is, using non-verbal means for conveying information to communicate, has recently attracted much scholarly attention. However, despite numerous investigations concerning various aspects of the problem, there is no agreement among researchers as regards terms to describe texts including both verbal and non-verbal information. Russian linguists Sorokin and Tarasov (1990) introduced the notion of "creolized text" to refer to texts consisting of two non-homogeneous parts, one of which belongs to the verbal sphere while the other one lies with sign systems other than natural languages. Although the term may seem a lucky one as far as its potential in describing the relevant language phenomenon is concerned and it has been widely used in works of Russian linguists (see, for example, Voroshilova 2007, Dubovitskaya 2012, Korda 2013, Platonova, Tarasova, Golubinskaya 2015), to Englishspeaking scholars it sounds confusing since it has strong associations with the notion of the mixture of cultures to which it is metaphorically related. In works of English-language researchers the word combination "visual-verbal text" is occasionally used to refer to the concept under discussion (see, for example, Economou 2009, Brooks 2009). However, in European and American tradition the said phenomenon is more commonly regarded through the prism of the multimodality concept. In accordance with the multimodal approach originally developed and further promoted by O'Halloran (1999), Goodwin (2000), Kress an van Leeuwen (2001), communication is assumed to draw upon a number of modes shaping the text meaning. Audio, video, graphs, photos, images, etc. are all seen as modes contributing to the overall text meaning. Since this approach has gained numerous followers among linguists and the term "multimodal" is familiar to many researchers, in this paper online retrospective monologues displaying features of deverbalization will be referred to as multimodal.

As indicated by results, at least two types of relations between visual and verbal components within multimodal retrospective monologues can be identified. Most commonly, the verbal part of the online retrospective monologue is autosemantic, that is, the visual constituent (an image or a photo) is optional. It is 
not of primary importance to the reader, and removing it from the body of the retrospective monologue will not affect its meaning. For instance, the monological utterance of the psychiatrist a passage from which is quoted in Example (6) above is accompanied by a photograph of a sad young woman looking into the distance and holding a baby in her arms. The photo is a supplementary element of her story, it helps the reader visualize the situation described by the monologist and promotes better understanding of her message. However, its role is not a crucial one, and the utterance will not lose in meaning if the image is not there.

This type of online retrospective monologues dominates over the other one (with the approximate ratio of 9:1) in which the visual component is obligatory. It becomes deeply incorporated into the structure of the utterance thus gaining meaningfulness and making the verbal part synsemantic. Example (8) below illustrates this statement:

(8) This photo was taken shortly after I proposed in 2014. I met my fiancee when I moved to London and started a new job - we worked in the same team and sat next to each other. We were good friends for over a year before I took the plunge and told her how I felt - fortunately she felt the same way and we started a relationship. [...] It might be a lot of people's worst nightmare spending all day everyday with your partner, but I was never happier at work than that time. [...] (FloydTheBarber 2016, Courtesy of Guardian News \& Media Ltd)

The monologue is a work love story published on the www.theguardian.com website in time for Valentine's Day. It was sent by FloydTheBarber, a reader who shared an episode from his personal life and illustrated it with a photo. In this case the image is an obligatory component of the story as it functions both as a basis for the plot and as supporting material.

Thus, incorporated visual elements, obligatory or optional, are unique to the structure of online retrospective monologues. As far as their content is concerned, the results also show declensions from standard practices of sharing autobiographical memories adopted in fiction. The online format of retrospective monologues in English CMD allows for innovations both in their structural and content-related characteristics. The latter are manifested primarily in the interactive nature of autobiographical recall reports published on the Internet. The high degree of interactivity shapes their content, which results in digital retrospective monologues containing links to other online resources, such as images, articles, blog posts, previous entries (in case of an online diary), etc. For example, in her post entitled "My university life as a woman professor" published on the Guardian website Sally Tomlinson recalls some landmark episodes in her academic career. Her story, a fragment from which is presented below, is rich in names and places, with web links provided to some of them: 
(9) Reading Rachel Williams' recent article, 'The professor is almost always white' (and male, of course), some moments in my own career came flooding back to me. Fortunately, most of them made me laugh. [...]

Elevation to a Chair, as it was then, in 1984, at Lancaster University, after six books in seven years, articles, chapters, large research grant, teaching popular with students, good administration, conference invitations and so on. [...]

Over the years I have tried to support male and female students and colleagues, especially when examining $\mathrm{PhD}$ dissertations [...], including that of Professor Heidi Mirza, whom Williams spoke to in her article. [...] (Tomlinson 2013, Courtesy of Guardian News \& Media Ltd)

Other interactive features include sharing tools, such as social media buttons, tags, and possibilities for commenting. The latter option is especially popular among readers of personal online diaries. Example (10) below is an entry from the Internet diary of the user writing as myterriblelife. The record is dated $5 \mathrm{Feb}-$ ruary, 2014 9:28 p.m. It reveals an episode from the personal life of the web diarist, specifically, related to her complex relationship with a love interest, and is followed by a commentary authored by andecreepo and a message next to a Facebook button informing that one person likes this record.

(10) So they broke up...agian I mean it usually happens it rearley works out going out agian after breaking up before. So two days after he asked me to walk home and I did he kissed me.. he hugged me and like took both my hands it was cute but confusing because I was kinda over talking to him and it started agian. I asked him if he was over his girlfriend and he told that he was and than on ask.fm he said he wasnt.....he told me i was pretty and said he didnt wanna date for a while and that he wanted to have a not date relationship with me atleast for a while but than he posts on ask that its hard being with someone for so long and than when losing them trying not to think about it. HE broke up with her thats why Im confused why he keeps saying that HE kissed me Its not fair to me either because i liked him IVE BEEN liking him idk if $i$ should just give up but if i do Im gonna always wonder what would have happend if $i$ didnt he changed cause of her he became a douche and a player and I dont know him anymore I guess I just miss the person I used to know so well What do I do now $\backslash$ ' ',

andecreepo The hardest part about loving someone is when they change, and you love someone who doesn't exist anymore. Keep your chin up and don't sell yourself short. If the person you fell for comes back, that would be great- but don't wait around. There's someone out there who's already the perfect guy and won't change because of another girl. ${ }^{4}$ (http://diary.com/myterriblelife\#)

As suggested by the results, the degree of interactivity of autobiographical memory reports published online is extremely high. The number of collected digital 
retrospective monologues displaying interactive features manifested in this or that form reached $92 \%$ of the total number of items in the database. The figures are consistent with the communicative intentions of most monologists as discussed above. Sharing past personal experiences on the Internet is indicative of the author's readiness for public exposure of private life and desire for feedback.

The qualitative analysis of collected data also showed other changes that occurred in the language of retrospective monologues as a result of their transition from print to screen. Those are totally determined by the Internet culture and include such features as deviations from orthographic norms, elements typical of casual spoken language, extensive use of emoticons, abbreviations, online slang words, etc. These details in greater or lesser degree were found in all of the collected instances of online retrospective monologues.

In her thesis on language of the Internet, Trávníková (2015: 42) states that computer-mediated communication "displays unifying stylistically significant features that are shared by all sub-varieties / modes that it involves". To develop her idea, one might say that the unifying power of computer-mediated communication extends further as to include not only sub-varieties and modes, but also forms and structures used as recurrent patterns for expressing similar meanings. To this the digital retrospective monologue is a good example as it has perfectly assimilated into the new communicative context by acquiring features typical of CMD.

With the development of online writing, the retrospective monologue seems to become a favourite form for presenting one's memories and past personal experiences in English CMD, the obvious advantage being its size. The age of the Internet and communication technologies has deprived users of the luxury of spending much time on reading enjoyed by previous generations. Today most bloggers and diarists cannot spend days and months writing long narratives as their readership will not have the time to read them anyway, so the monologue strengthens its positions as a format for digital self-expression.

Another possible reason for the retrospective monologue changing its common habitation areal, as I see it, is that verbalized in the monological form, the past, quoting Cohn (1983: 246), "is always anchored in the present moment of locution, and thus commented and exclaimed upon rather than plainly narrated". Publicity, accessibility, and feedback are fundamental to the Internet, hence the growing popularity of the online retrospective monologue which easily meets the requirements.

\section{Conclusion}

The retrospective monologue as a linguistic and literary phenomenon has gone a long way from a stage soliloquy in Greek tragedies and a poetic device (sometimes masked as an apostrophe (Richmond 2015)), rendering dramatic expression to the lyrics of Dante, Petrarch, Villon, Chaucer and other poets of the postclassical 
period till it became a literary technique highly popular among authors of stream of consciousness novels. With the arrival of new communication technologies allowing an instant exchange of messages, posting textual, graphical and video content and commenting on it in real-time mode, there emerged new forms of representing one's thoughts, memories and impressions while some old ones developed new properties. As indicated by the results obtained in the course of this inquiry, the retrospective monologue is an open form allowing many modifications, capable of functioning in different genres and modes.

This paper also sets an avenue for future research into how traditional linguistic devices evolved along with our ways of communication and adapted to new linguistic conditions. A more detailed investigation covering more linguistic aspects and employing a larger database of examples could provide an insight into how people of different age, gender, cultural and social background share their autobiographical memories online.

Application of linguistic instruments to the study of the retrospective monologue, which was once a purely narratological concept, yields results suggestive of the need to review long established facts and concepts as to reveal their new structural and functional potential under the changing linguistic conditions. The basic idea advanced hereby is that linguists would do well to turn their attention to well-known and thoroughly discussed language phenomena to see the excitingly new role they perform today.

\section{Notes}

1 Due to copyright restrictions, the author was unable to include full texts of retrospective monologues and images featured in this article. Please follow the links provided in the list of references to view the full-text versions and images.

2 First cases of retrospection as a narrative device were registered in ancient folklore and literary texts (Likhachov 1971) while retrospective monologues were known in Greek dramas, Aeschylus tragedies being a good example.

$320^{\text {th }}$ century drama and prose.

4 Original grammar, punctuation, and spelling have been preserved.

\section{Acknowledgement}

The results of the research project are published with the financial support of Tula State University within the framework of the scientific project \#2017-11PUBL.

\section{References}

Abrantes, Ana Margarida (2010) Meaning and Mind: A Cognitive Approach to Peter Weiss' Prose Work. Frankfurt am Main: Peter Lang. 
Anderson, Linda (2001) Autobiography (The New Critical Idiom). Oxon: Routledge.

Anderson, Linda (1996) Women and Autobiography in the Twentieth Century: Remembered Futures. New York: Prentice Hall.

Bal, Mieke (2004) Narrative Theory: Special topics. London, New York: Taylor \& Francis.

Brooks, Kevin. (2009) 'More "Seriously Visible" Reading: McCloud, McLuhan, and the Visual Language of The Medium Is the Massage'. College Composition and Communication 61(1), W217-W237. http://www.ncte.org/library/NCTEFiles/Resources/Journals/CCC/0611-sep09/ CCC0611More.pdf. Accessed on November 11, 2015.

Chafe, Wallace (1990) 'Some things that narratives tell us about the mind'. In: Britton, Bruce K., Pellegrini, Anthony D. (eds.) Narrative Thought and Narrative Language, 79-98. Hillsdale, NJ: Erlbaum.

Chiu, Monica (2014) Drawing New Color Lines: Transnational Asian American Graphic Narratives. Hong Kong University Press.

Cohn, Dorrit (1983) Transparent Minds. Narrative Modes for Presenting Consciousness in Fiction. Princeton: Princeton University Press.

December, John (1996) 'What is Computer-mediated Communication?' http://www.december. $\mathrm{com} / \mathrm{john} / \mathrm{study} / \mathrm{cmc} /$ what.html Accessed on January 19, 2016.

Dubovitskaya, Lyubov (2012) 'Znakovost' kreolizovannogo teksta pis'mennoi kommunikatsii (Sign Chracter of Written Creolized Texts)'. Vestnik Moskovskogo Gosudarstvennogo Oblastnogo Universiteta 2. http://www.evestnik-mgou.ru/Articles/Doc/190 Accessed on February 1, 2016.

Economou, Dororthy (2009) Photos in the News: appraisal analysis of visual semiosis and verbalvisual intersemiosis. Doctor of Philosophy thesis. Sydney: University of Sydney. http://hdl.handle.net/2123/5740 Accessed on September 12, 2015.

Eggins Suzanne and Diana Slade (2005) Analysing Casual Conversation. London: Equinox Publishing Ltd.

Finlayson Mark A. and Steven R. Corman (2013) 'The Military Interest in Narrative'. Sprache und Datenverarbeitung, Special Issue on Formal and Computational Models of Narrative 37(1-2), 173-191.

Fivush, Robyn (2011) 'The Development of Autobiographical Memory'. Annual Review of Psychology 62, 559-582.

Fludernik, Monika (2004) 'Extract from 'Virgin Territories: The strategic expansion of deictic options'. In Bal, Mieke (ed.) Narrative Theory. Critical Concepts in Literary and Cultural Studies. Vol. II. Special Topics. London and New York: Routledge, 56-92.

Goodwin, Charles (2000) 'Action and embodiment within situated human interaction'. Journal of Pragmatics, 32: 1489-1552.

Gottskálk, Jensson (2004) The Recollections of Encolpius: The Satyrica of Petronius as Milesian Fiction. Groningen: Barkhuis.

Guseva, Galina V. (2003) 'K voprosu o vnutrennem monologue kak raznovidnosti pis'mennogo diskursa (On interior monologue as a variety of written discourse)'. Izvestiya Tul'skogo Gosudarstvennogo Universiteta, Philologicheskie Nauki 3, 55-63.

Harty, John Francis (2009) Oscillation in Literary Modernism. Frankfurt am Main: Peter Lang.

Herring, Susan C. (2001) 'Computer-mediated Discourse'. In: Schiffrin, Deborah, Deborah Tannen and Heidi E. Hamilton (eds.) The Handbook of Discourse Analysis. Oxford: Blackwell Publishers, 612-634.

Humphrey, Robert (1954) Stream of Consciousness in the Modern Novel. Berkeley: University of California Press.

Ioannidou, Stavrini (2013) Autofiction a la grècques: Greek autobiographical fiction (1971-1995). Unpublished $\mathrm{PhD}$ thesis. London: King's College London.

King, Nicola (2000) Memory, Narrative, Identity. Remembering the Self. Edinburgh: Edinburgh University Press. 
Kirillova, Tatyana (2011) Vnutrennyaya rech $v$ aspekte intrapersonal'noi kommunikatsii (Interior speech in the context of interpersonal communication). Unpublished PhD thesis. Samara: Samara State University of Economics.

Korda, Olga (2013) Kreolizovannyi tekst v sovremennykh pechatnykh SMI: strukturnofunktsional'nye kharakteristiki (Creolized text in present-day print press: structural and functional characteristics). Unpublished $\mathrm{PhD}$ thesis. Ekaterinburg. http://elar.urfu.ru/bitstream/10995/18959/1/urgu1208s.pdf Accessed on July 13, 2015.

Kress, Gunther and Theo van Leeuwen (2001) Multimodal Discourse: The Modes and Media of Contemporary Communication. Oxford UK: Oxford University Press.

Kucała, Boźena (2017) 'Penelope Lively's Autobiographical Memory'. Brno Studies in English 43(1): 157-169.

Labov, William (1972) Language in the Inner City. Oxford: Basil Blackwell.

Likhachov, Dmitriy S. (1971) Poetika drevnerusskoi literatury (Poetics of Old Russian Literature). Leningrad: Khudozhestvennaya Literatura.

Linde, Charlotte (1993) Life Stories: The Creation of Coherence. New York: Oxford University Press.

Martin, James Robert and David Rose (2008) Genre Relations: Mapping Culture. London: Equinox.

Nelson, Katherine (2003a) 'Narrative and Self, Myth and Memory: Emergence of the Cultural Self'. In: Fivush, Robyn, Haden Catherine A. (eds.) Autobiographical Memory and the Construction of a Narrative Self: Developmental and Cultural Perspectives. Mahwah and London: Lawrence Erlbaum Associates Publishers, 3-28.

Nelson, Katherine (2003b) 'Self and social functions: Individual autobiographical memory and collective narrative'. Memory 11 (2): 125-136.

Nikolajeva, Maria (2002) The Rhetoric of Character in Children's Literature. Lanham, MD: Scarecrow Press.

O'Halloran, Kay L. (1999) 'Towards a Systemic Functional Analysis of Multisemiotic Mathematics Texts'. Semiotica, 124(1/2), 1-29.

Olney, James (1998) Memory and Narrative: The Weave of Life-Writing. Chicago: University of Chicago Press.

Paterson, Eddie (2015) The Contemporary American Monologue: Performance and Politics. London, New York: Bloomsbury Publishing.

Phillpotts, Bertha (2011) The Elder Edda and Ancient Scandinavian Drama. Cambridge: Cambridge University Press.

Platonova Iuliia, Elena Tarasova and Anastasia Golubinskaya (2015) 'Creolized Text as a form of Modern Educational Discourse'. Procedia - Social and Behavioral Sciences. Worldwide trends in the development of education and academic research 214, 788-796. http://www.sciencedirect. com/science/article/pii/S1877042815060747 Accessed on January 30, 2016.

Plum, Guenter A. (1988) Text and Contextual Conditioning in Spoken English. A genre-based approach. Vol. 1. Ph.D. Thesis. http://www.isfla.org/Systemics/Print/Theses/PlumThesisVol1.pdf. Accessed on March 14, 2017.

Richardson, Brian (2016) Unnatural Voices: Extreme Narration in Modern and Contemporary Fiction. Columbus: Ohio State University Press.

Richmond, Hugh M. (2015) The School of Love: The Evolution of the Stuart Love Lyric. Princeton: Princeton University Press.

Rothery, J. and M. K. Stenglin (1997) 'Entertaining and instructing: exploring experience through story'. In: Christie, Frances and James Robert Martin (eds.) Genre and Institutions: Social Processes in the Workplace and School. London: Cassell, 231-263.

Russo, Carlo Ferdinando (2002) Aristophanes: An Author for the Stage. London: Routledge.

Schroeder, Patricia R. (1989) The Presence of the Past in Modern American Drama. Madison, NJ: Fairleigh Dickinson University Press. 
Sergeeva, Yuliya M. (2009) Vnutrennyaya rech kak osobaya forma obscheniya (Interior speech as a special form of communication). Unpublished PhD thesis. Moscow: Moscow State Pedagogical University.

Sharma, Siddhartha (2004) Arun Joshi's Novels: A Critical Study. New Delhi: Atlantic Publishers \& Dist.

Smith, Sidonie (1987) A Poetics of Women's Autobiography: Marginality and the Fictions of SelfRepresentation. Bloomington: Indiana University Press.

Smith, Sidonie and Julia Watson (2010) Reading Autobiography: A Guide for Interpreting Life Narratives. Minneapolis, London: University of Minnesota Press.

Smith, Sidonie and Julia Watson (1998) Women, Autobiography, Theory: A Reader (Wisconsin Studies in American Autobiography). Madison: University of Wisconsin Press.

Sorokin, Yuriy A., Tarasov Evgeniy F. (1990) 'Kreolizovannyje teksty i ikh kommunikativnaya funktzija (Creolized texts and their communicative function)'. In: Kotov, Roman G. (ed.) Optimizatzija rechevogo vozdejstviya (Optimization of a speech effect). Moscow: Vysshaja shkola, 180-186.

Tani Franca, Andrea Smorti and Carole Peterson (2015) 'Is friendship quality reflected in memory narratives?' Journal of Social and Personal Relationships 32 (3): 281-303.

Tivyaeva, Irina (2014) 'Representation of retrospective memory and communicative context'. Jezikoslovlje 15(2-3): 283-306.

Trávníková, Petra (2015) Language of the Internet: Positive Politeness Strategies Claiming Common Ground in Asynchronous Computer-Mediated Communication. A Socio-Pragmatic Analysis. PhD Dissertation. Brno: Masaryk University.

Tumanov, Vladimir (1997) Mind Reading: Unframed Interior Monologue in European Fiction. Amsterdam and Atlanta: Rodopi.

Voroshilova, Maria (2007) 'Kreolizovannyi tekst: aspekty izucheniya (Creolized text: aspects of study)'. Politicheskaya lingvistika (Political Linguistics) 21: 75-80. http://cyberleninka.ru/ article/n/kreolizovannyy-tekst-aspekty-izucheniya-1. Accessed on April 21, 2011.

\section{Sources}

Anonymous (2016) I saved a baby from growing up without a mother. The Guardian. 11 February 2016. http://www.theguardian.com/healthcare-network/2016/feb/11/saved-baby-growing-upwithout-mother-postnatal-depression Accessed on 25 February 2016.

Dettmer, J. (2012) Syrian Army Accused of Vicious, Systematic Rape. The Daily Beast. 13 August, 2012. http://www.thedailybeast.com/articles/2012/08/13/syrian-army-accused-of-vicioussystematic-rape.html Accessed on October 10, 2013.

FloydTheBarber (2016) From awkward flirting by the water fountain to marriage. The Guardian. 12 February 2016. http://www.theguardian.com/careers/2016/feb/12/i-told-my-wife-she-wasbeing-made-redundant-your-office-romance-stories Accessed on 17 February 2016.

Greenwood, Georgina (2015) Last night I delivered my first baby. It didn't go to plan but it was incredible. The Guardian. 30 July 2015. http://www.theguardian.com/healthcare-network/2015/ jul/30/delivered-first-baby-incredible-midwife Accessed on 7 December 2015.

Oates, Joyce Carol (2009) Upholstery. In: Oates, Joyce Carol. I Am No One You Know: And Other Stories. Zondervan, 105-116.

Patterson, James, Roughan, Howard (2008) You've Been Warned. Vision. 2008.

Pergament, D. (2008) Survival Sex: Iraqi Refugees. MarieClaire, 14 July 2008. http://www.marieclaire.com/world-reports/news/iraqi-refugees-prostitutes-sex?click=rel Accessed on 21 February 2015.

Pesta, A. (2011) Diary of an Escaped Sex Slave. Marie Claire. July 20, 2011. http://www.marieclaire.com/world-reports/news/diary-escaped-sex-slave. Accessed on October 11, 2013. 
Tomlinson, Sally (2013) My university life as a woman professor. The Guardian. 31 January 2013. http://www.theguardian.com/higher-education-network/blog/2013/jan/31/female-professor-university-life-equality. Accessed on 25 June 2014.

IrIna Tivyaeva is Associate Professor at the Department of Linguistics and Translation Studies, Tula State University, Russia. She received her Ph.D. in Germanic Languages from Voronezh State University, Russia in 2007. Her main areas of research are memory studies, psycholinguistics, discourse analysis and teaching English as a foreign language. Irina Tivyaeva has published several papers focused on specifics of representing individual memory and its processes in communication.

Address: Irina Tivyaeva, Ph.D., Department of Linguistics and Translation Studies, Institute of Humanities and Social Sciences, Tula State University, prospect Lenina 92, Tula, 300012, Russia. [email: tivyaeva@yandex.ru] 